\title{
BEBERAPA FAKTOR RISIKO YANG BERHUBUNGAN DENGAN PENYAKIT PARU OBSTRUKTIF KRONIK (PPOK) PETUGAS KEBERSIHAN DI KOTA PURWOKERTO TAHUN 2017
}

\author{
MONALISA FAJAR ASTUTI *) BUDI UTOMO**) SUPARMIN***) \\ Jurusan Kesehatan Lingkungan Politeknik Kesehatan Kemenkes Semarang, \\ Jl. Raya Baturaden KM 12 Purwokerto, Indonesia
}

\begin{abstract}
Abstrak
$\mathrm{XVI}+101$ halaman, gambar, tabel, lampiran

Penyakit paru obstruktif kronik adalah suatu penyakit dengan karakteristik keterbatasan saluran napas yang irreversible, biasanya progresif, dan berhubungan dengan respon inflamasi dikarenakan bahan yang merugikan atau gas. Inflamasi pada PPOK dapat terjadi dari paparan iritan yang kronik seperti asap rokok dan polusi udara. Tujuan dari penelitian ini adalah mengetahui beberapa faktor risiko yang berhubungan dengan penyakit paru obstruktif kronik (PPOK).Besar sampel 80 responden dari 247 petugas kebersihan. Cara pengambilan sampelnya semua petugas kebersihan yang PNS Menggunakan metode Cross Sectional. Menghubungkan umur, perilaku merokok, dan perilaku memakai masker dengan PPOK. Hasil penelitian yaitu tidak ada hubungan antara umur, perilaku merokok, dan perilaku memakai masker dengan penyakit paru obstruktif kronik, niilai $\rho=1,000, \rho=0,180$, dan $\rho=0,637$. Hasil pengukuran kapasitas paru $74(92,5 \%)$ PPOK dan $6(7,5)$ tidak PPOK. Suhu pada setiap titik pengukuran yaitu $\left(26,5^{\circ} \mathrm{C}\right),\left(33^{0} \mathrm{C}\right),\left(30^{\circ} \mathrm{C}\right),\left(25^{\circ} \mathrm{C}\right),\left(31^{\circ} \mathrm{C}\right)$, dan $\left(36^{\circ} \mathrm{C}\right)$. Kelembaban yaitu $(76,60,78,77$, dan 42$)$.Simpulan dari penelitian ini dari variabel yang ditentukan peneliti tidak ada hubungan antara umur, perilaku merokok, dan perilaku memakai masker dengan penyakit paru obstruktif kronik. Besar sampel dapat lebih ditingkatkan dan kriteria sampel agar lebih dikendalikan.
\end{abstract}

Daftar Bacaan : 30 (2001-2017)

Kata Kunci : : Umur, perilaku merokok, perilaku memakai masker, dan PPOK

Klasifikasi : :

Abstract
$\mathrm{XVI}+101$ pages, images, tables, attachments
Chronic obstructive pulmonary disease is a disease with irreversible airway limitation
characteristics usually progressive, and are associated with an inflammatory response due to
adverse materials or gases.

*fajarmonalisa@gmail.com

**budut17@yahoo.co.id

***pakparmin@yahoo.com 
Infammation can occur froom chronic irritant exposure such as cigarette smoke and air pollution. The purpose of this study was to examine several risk factors associated with chronic obstructive pulmonary disease. A sample size of 80 respondents from 247 janitors (cleanship officers). How to take the samples of all the civil servants (PNS). Which is use the cross sectional method. Associated age, smoking behavior, and behavior wear mask with chronic obstructive pulmonary disease.The result of research is there is no relation between age, smoking behavior, and behavior wear mask with chronic obstructive pulmonary disease (PPOK), value $\rho=1.000, \rho=0.180$, and $\rho=0.637$. results of measurement of lung capacity 74 (92.5\%) PPOK and 6 (7.5\%) are not PPOK. Temperatures at each measurement point are $\left(26,5^{\circ} \mathrm{C}\right),\left(33^{\circ} \mathrm{C}\right),\left(30^{\circ} \mathrm{C}\right),\left(25^{\circ} \mathrm{C}\right),\left(31^{\circ} \mathrm{C}\right)$, and $\left(36^{\circ} \mathrm{C}\right)$. Humidity is $(76 \%, 60 \%, 78 \%, 77 \%$, dan $42 \%)$. The conclusions of this study of the variables determined by researchers there is no relationship between age, smoking behavior, and the behavior of wearing a mask with chronic obstructive pulmonary disease. The sample size can be further improved and the sample criteria to be more controlled.

\section{Reading List : 30 (2001-2017) Keywords : Age, smoking behavior, wearing mask behavior, and PPOK Classification : -}

\section{Pendahuluan}

Who (World Health Organization) menyatakan bahwa tahun 2008, penyakit paru obstruktif kronik diperkirakan menjadi penyebab kematian ketiga pada tahun 2030. Sedangkan menurut Global Initiative For Chronic Obstructive Lung Disease (GOLD), Penyakit Paru Obstruktif Kronik (PPOK) sendiri adalah penyakit yang dengan karakteristik keterbatasan saluran napas yang tidak sepenuhnya reversible. Keterbatasan saluran napas tersebut biasanya progresif dan berhubungan dengan respons inflamasi dikarenakan bahan yang merugikan atau gas.

Angka kecacatan karena PPOK meningkat dari urutan ke-9 menjadi urutan ke-5 pada tahun 2020 (Marieadelaide, 2009). Pada tahun 2015 PPOK merupakan penyebab kematian ke-4 di dunia (Decramer et al, 2015). Hasil RISKEDAS (2013) menyatakan bahwa prevalensi PPOK di Indonesia sebesar 3,7\%. Prevalensi PPOK diperkirakan akan meningkat sehubungan dengan peningkatan usia harapan hidup penduduk dunia, pergeseran pola dari penyakit infeksi ke penyakit degeneratif serta meningkatnya kebiasaan merokok dan polusi udara (Tjahjono, 2011)

Di negara berkembang para pekerja biasanya mendapatkan kondisi kerja yang buruk, upah rendah, dan jam kerja lama, tidak ada cuti dan akses terhadap pelayanan kesehatan yang rendah. Prevalensi penyakit paru akibat pencemaran udara akibat kendaraan bermotor di lingkungan kerja, misalnya pada petugas kebersihan. Belum banyak diketahui dan datanya tidak tersedia dan merupakan pekerjaan yang berdekatan dengan kendaraan yang melewati jalan sehingga memungkinkan terjadinya pencemaran udara dan para pekerja di masingmasing area. Dengan bekerja sebagai petugas kebersihan di jalan memiliki risiko yang membahayakan kesehatan, khususnya kesehatan pernafasan. Sedangkan PPOK merupakan salah satu penyakit tidak menular utama, yang jarang terekspose karena kurangnya informasi yang diberikan.

Studi kasus di Desa Darmakradenan Kecamatan Ajibarang Kabupaten Banyumas tentang faktor faktor risiko penurunan kapasitas paru pekerja tambang batu kapur, hasil studi pengukuran kapasitas paru terhadap 283 pekerja diketahui 24,0\% kapasitas paru normal, 28,6 \% restriksi, 16,2 \% obstruksi dan 31,1 \% kombinasi restriksi dan obstruksi. Hal ini menunjukan ada kenaikan prevalensi penurunan kapasitas paru pekerja tambang batu kapur dari 24,0 \% tahun 1997 menjadi 75\% tahun 2004 (Budi Utomo, 2005).

Petugas kebersihan di Kota Puwokerto, untuk mendukung pertumbuhaan perekonomian masyarakat sekitar, dalam bentuk membuat kota bebas sampah setiap hari dari kegiatan menyapu juga dapat menimbulkan debu yang diudara, yang pada akhirnya dapat terpaparpada petugas kebersihan dan masyarakat. Guna menekan dampak negatif tersebut perlu adanya pengawasan kesehatan tenaga kerja.

Pengawasan keselamatan dan kesehatan kerja merupakan hal yang wajib dilaksanakan oleh pekerja kebersihan, berupa penggunaan alat pelindung diri (APD) berupa masker, kaos tangan, sepatu boat, wearpack, hlem, dan kacamata.

Hal-hal yang perlu diperhatikan dalam rangka perlindungan terhadap tenaga kerja di antaranya penggunaan masker, upah yang layak, jaminan sosial yang memadai, kondisi kerja yang aman, nyaman, dan selamat yang pada gilirannya akan diperoleh tenaga kerja yang sehat efisien dan produktif. Salah satu faktor penyebab adalah partikel 
debu, dimana seorang pekerja kebersihan tidak menggunakan APD yang sesuai. Di samping itu melalui proses fisik dan kimia pembakaran bahan bakar minyak dari kendaraan lalu lintas yang padat yang menghasilkan partikel debu dan senyawa kimia lain (CO, $\mathrm{CO}_{2}, \mathrm{HCO}$ ). Debu akan mencemari lingkungan, sehingga pekerja maupun masyarakat sekitar dapat terpapar oleh debu.

Petugas Kebersihan dalam melaksanakan tugas sehari-hari bekerja di jalan raya dengan tingkat kepadatanlalu lintas Kota Banyumas, terutama pada jalan yang macet. Partikel debu akan memperburuk kualitas udara, sehingga terjadi akumulasi partikel debu dalam tubuh yang mungkin dapat mempengaruhi penurunan kapasitas paru kinerja petugas kebersihan. Paparan debu dalam tubuh pekerja kebersihan dimungkinkan memiliki kadar yang bervariasi.

Data survei pendahuluan, petugas kebersihan di wilayah Kota Purwokerto jumlahnya 247, mereka bertugas di jalan raya di wilayah Kota Purwokerto dengan lama jam kerja7 jam/hari dengan ketentuan mulai bekerja shift pagi hari jam $05.00-12.00$, siang 12.00 - 19.00, dan malam19.00 - 24.00 WIB jarak setiap pekerja kebersihan 1000 - 1500 M, sehingga mereka merupakan salah satu kelompok yang berpotensi untuk terpapar partikel debu. Mereka setiap hari akan terpapar oleh partikel debu. Paparan debu dengan dosis tinggi secara terus menerus yang berlangsung lama memiliki risiko terhadap sistem saluran pernafasan.

Tujuan dari penelitian ini

a. Mengetahui beberapa faktor risiko yang berhubungan dengan penyakit paru obstruktif kronik (PPOK).

b. Mendeskripsikan karakteristik umur, perilaku merokok, dan perilaku memakai masker (APD) petugas kebersihan

c. Mengukur kejadian paru obstruktif kronik

d. Menganalisis hubungan umur dengan kejadian PPOK

e. Menganalisis hubungan perilaku merokok dengan kejadian PPOK

f. Menganalisis hubungan perilaku memakai masker dengan kejadian PPOK

Manfaat Penelitian

1. Bagi Pekerja Kebersihan

Memberikan informasi tentang bahaya yang ditimbulkan oleh pencemaran udara seperti debu, khususnya dalam paru-paru di lingkungan kerja yang nantinya dapat dijadikan referensi kedepan dapat menentukan nilai ambang batas (NAB) kadar debu dalam paruparu .

2. Bagi Poltekkes Kemenkes Semarang

Menambah perbendaharaan bacaan atau kepustakaan di perpustakaan Poltekkes Kemenkes Semarang Jurusan Kesehatan Lingkungan Purwokerto, dan menambah wawasan pengetahuan mahasiswa.

3. Bidang pelayanan Masyarakat

Memberikan informasi kepada masyarakat terutama yang sering terpapar partikel-partikel debu terhadap penyakit paru obstruktif kronik (PPOK), salah satunya petugas kebersihan.

4. Bagi peneliti

Dapat menambah pengetahuan mengenai beberapa faktor risiko yang berhubungan dengan penyakit paru obstruktif kronik pada petugas kebersihan.

\section{Penyakit Paru Kerja}

Penyakit paru kerja adalah penyakit atau kelainan paru yang timbul sehubungan dengan pekerjaan. Berbagai zat seperti debu, serat dan gas dapat timbul pada proses produksi dalam industri. Tergantung pada jenis zattersebut, maka penyakit yang ditimbulkan juga bermacam-macam. Berdasarkan jenis penyebab, penyakit paru kerja dibedakan atas (Budi Utomo, 2005)

1. Penyakit paru kerja interstitial, dapat disebabkan oleh asbes, batubara, silika, birilium, jamur dan antigen burung. Penyakit paru kerja ini disebut hipersensitive pneumonia.

2. Edema paru, dapat disebabkan oleh asap, nitrogen, dan $\mathrm{SO}_{2}$

3. Penyakit pleura (efusi pleura), dapat disebabkan oleh asbes

4. Bronchitis, dapat disebabkan oleh debu tepung, debu berat pada pekerja batu kapur dan batu bara.

5. Asma, dapat disebabkan oleh bulu binatang, toluen, garam platina, tepung dan debu kapas.

6. Karsinoma bronkus, dapat disebabkan oleh uranium, asbes, krom, nikel, klormetil dan metil eter.

7.

Penyakit Paru Obstruktif Kronik

PPOK adalah penyakit paru kronik yang ditandai oleh hambatan aliran udara di saluran napas yang bersifat progressif nonreversibel atau reversibel parsial.PPOK terdiri dari bronkitis kronik dan emfisema atau gabungan 
keduanya (Perhimpunan Dokter Paru Indonesia 2003).

PPOK didefinisikan sebagai penyakit yang dapat dicegah dan ditangani dengan efek EKSTRAPULMONER signifikan yang dapat mempengaruhi beratnya penyakit.Penyakit ini ditandai dengan hambatan aliran udara di saluran nafas yang tidak sepenuhnya reversible.Hambatan aliran udara ini bersifat progresif dan berhubungan dengan respon inflamasi paru terhadap partikel atau gas yang beracun atau berbahaya (Depkes RI, 2008).

Dalam menilai gambaran klinis pada PPOK harus memperhatikan hal-hal berikut ini :

1. Onset (awal terjadinya penyakit) biasanya pada usia pertengahan.

2. Perkembangan gejala biasanya bersifat progresif lambat

3. Riwayat pajanan, seperti merokok, polusi udara (di dalam/luar ruangan, tempat kerja)

4. Sesak nafas pada saat melakukan aktifitas

5. Hambatan aliran udara pada umumnya ireversibel (tidak bisa kembali normal)

Menurut perkiraan WHO 65 juta penduduk dunia telah menderita PPOK.Lebih dari 3 juta orang meninggal akibat PPOK pada tahun 2005, yang merupakan 5\% dari kematian global di seluruh dunia.Hampir 90\% kematian akibat PPOK terjadi di negara-negara dengan pendapatan rendah dan menengah.Tahun 2002 PPOK telah menduduki peringkat 3 penyebab kematian setelah kardiovaskuler dan kanker. Total kematian dari PPOK diperkirakan meningkat lebih dari 30\% dalam 10 tahun mendatang jika tidak dilakukan tindakan pengurangan faktor risiko. PPOK merupakan penyebab kematian ke-3 di Amerika Serikat.Tahun 2030 diperkirakan PPOK menjadi penyebab kematian peringkat ke-1 di dunia (WHO, 2012).

Studi yang dilakukan pada 12 negara asia pasifik, prevalensi kejadian PPOK pada individu dewasa (usia $>30$ tahun) adalah sebanyak 6,3\% penduduk. Dengan prevalensi terendah yaitu $3,5 \%$ (Hongkong dan Singapura) dan tertinggi $6,7 \%$ (Vietnam) (Global, 2011). Berdasarkan ekstrapolasi data statistik dari data base internasional diperkirakan terdapat 13 juta penduduk Indonesia yang menderita PPOK (US Census Bureau, 2012).

Penurunan kadar oksigen dalam sirkulasi dan jaringan tubuh, menempatkan pasien pada risiko tinggi komplikasi sistemik yang meliputi peradangan sistemik, penurunan berat badan, gangguan muskuloskeletal, gangguan kardiovaskular, gangguan hematologi, neurologi dan psikiatri (Khader, 2007).

Patogenisis dan patologi

Pada bronkitis kronik terdapat pembesaran kelenjar mukosa bronkus, metaplasia sel goblet, inflamasi,hipertrofi otot polos pernapasan serta distorsi akibat fibrosis.Emfisema ditandai oleh pelebaran ronggaudara distal bronkiolus terminal, disertai kerusakan dinding alveoli. Secara anatomik dibedakan tiga jenisemfisema:

- Emfisema sentriasinar, dimulai dari bronkiolus respiratori dan meluas ke perifer, terutama mengenai bagian atas paru sering akibat kebiasaan merokok lama.

- Emfisema panasinar (panlobuler), melibatkan seluruh alveoli secara merata dan terbanyak pada paru bagian bawah.

- Emfisema asinar distal (paraseptal), lebih banyak mengenai saluran napas distal, duktus dan sakus alveoler. Proses terlokalisir di septa atau dekat pleura

Obstruksi saluran napas pada PPOK bersifat ireversibel dan terjadi karena perubahan struktural pada saluran napas kecil yaitu : inflamasi, fibrosis, metaplasi sel goblet dan hipertropi otot polos penyebab utama obstruksi jalan napas.

Faktor - Faktor Risiko

1. Umur

Semakin bertambah umur seseorang maka akan terjadi degenerasi otot-otot pernafasan dan elastisitas jaringan menurun. Sehingga kekuatan otot-otot pernafasan dalam menghirup oksigen menjadi menurun.Kemudian karena faktor umur yang bertambah maka semakin banyak alfeoli yang rusak dan daya tahan tubuh semakin rendah.

Hasil penelitian Setiyanto di ruang rawat inap RS Persahabatan Jakarta selama April 2005 sampai April 2007 menunjukkan dari 120 penderita PPOK, usia termuda adalah 40 tahun dan tertua adalah 81 tahun. Dilihat dari riwayat merokok, hampir semua pasien adalah bekas perokok sebanyak 109 penderita dengan proporsi sebesar (90,83\%).

2. Perilaku merokok 
Kebiasaan merokok diketahui mekanisme pertahanan respirasi. Produk asap rokok diketahui merangsang produksi mukus dan menurunkan pergerakan silia. Penurunan pergerakan silia dapat merangsang terjadinya akumulasi mukus yang kental dan terperangkapnya partikel. (H.J. Mukono, 2010).

Merokok pada orang dewasa dapat menimbulkan berbagai gangguan sistem pernafasan seperti kanker paru, gejala iritan akut, asma, gejala pernafasan kronik, penyakit paru obstruktif kronik, infeksi pernafasan (Tarlo, dkk, 2010).

Akibat perubahan anatomi saluran nafas pada perokok akan timbul perubahan pada kapasitas dengan segala macam gejala klinisnya. Hal ini merupakan penyebab terutama terjadinya penyakit obstruksi menahun. (PPOM) (Bahar,2003 : Lightower et al, 2003)

Menurut hasil penelitian Shinta di RSU dr Soetomo Surabaya pada tahun 2006 menunjukkan bahwa dari 46 penderita PPOK, 29 orang diantaranya (63\%) adalah perokok.

3. Perilaku memakai masker (APD) Alat Pelindung Diri (APD) Alat pelindung diri merupakan alat yang dipakai oleh pekerja untuk memproteksi dirinya dari kecelakaan yang terjadi akibat pekerjaannya.APD yang dimaksud untuk mengurangi absorbsi partikel debu adalah masker.Diharapkan dengan pemakaian APD ini dapat menurunkan tingkat risiko bahaya penyakit dari paparan $\mathrm{Pb}$ dan partikel debu yang bisa diakibatkan oleh pekerjaannya. Kebiasaan memakai masker yang baik akan mengurangi dan melindungi kesehatan.

Masker berfungsi untuk menghalangi partikel berbahaya yang dapat masuk ke pernafasan. Seperti gas, uap, debu, atau udara yang mengandung polutan, racun dan substansi lain yang mengganggunya. Oleh karena itu penggunaan masker dapat menjadi alat pelindung untuk mencegah manusia menghirup partikulat yang berbahaya. (Alya Mutiara Basti, 2014).

4. Partikel Debu

Debu adalah zat kimia padat yang disebabkan oleh kekuatan-kekuatan alami atau mekanis seperti penggolongan, penghancuran, pelembutan, pengepakan yang cepat, peledakan, dan benda, baik organik maupun anorganik (Suma'mur, 2009).

Debu adalah partikel yang dihasilkan oleh proses mekanis. Jadi, pada dasarnya pengertian debu adalah partikel yang berukuran kecil sebagai hasil dari proses alami maupun mekanik (Departemen Kesehatan RI, 2003).

1. Macam-macam debu

a. Debu organik

Seperti debu kapas, debu daun-daunan

b. Debu mineral

Merupakan debu yang berasal dari senyawa komplek seperti debu arang batu, debu silika, debu batu bara, debu kapur.

c. Debu metal

Seperti debu Timah Hitam, debu Arsen, debu Kadmium

2. Sifat-sifat debu

Menurut Departemen Kesehatan RI yang dikutip oleh Mengkidi ( 2006 ), partikel partikel diudara mempunyai sifat :

a. Sifat pengendapan

Sifat pengendapan adalah sifat debu yang cenderung selalu mengendap karena gaya gravitasi bumi. Namun karena kecilnya ukuran debu, kadang -kadang debu ini relatif tetap berada diudara.

b. Sifat permukaan basah

Sifat permukaan debu akan cenderung selalu basah, dilapisi oleh lapisan air yang sangat tipis. Sifat ini penting dalam pengendalian debu dalam tempat kerja.

c. Sifat pengumpulan

Permukaan debu selalu basah, sehingga dapat menempel satu sama lain dan dapat menggumpal. Turbulensi udara meningkat pembentukan pengumpulan debu.Kelembaban dibawah saturasi, kecil pengaruhnya terhadap pengumpulan debu.Kelembaban yang melebihi tingkat huminitas diatas titik saturasi mempermudah pengumpulan debu.Oleh karena itu partikel debu bisa merupakan inti daripada air yang berkonsentrasi sehingga partikel menjadi besar.

d. Sifat listrik statis

Debu mempunyai sifat listrik statis yang dapat menarik partikel lain yang berlawanan. Dengan demikian, partikel dalam larutan debu mempercepat terjadinya proses pengumpulan.

e. Sifat optis 
Partikel debu basah atau lembab lainnya dapat memancarkan sinar yang terlihat dalam kamar gelap.

3. Ukuran partikel debu

Debu merupakan partikel padat yang mempunyai ukuran diameter 0,1-50 mikron atau lebih. Partikel debu yang besar dengan ukuran lebih besar dari 50 mikron hanya dapat dideteksi dengan mata biasa jika terdapat pantulan cahaya yang kuat dari partikel debu tersebut. Partikel yang berukuran kurang dari 10 mikron dapat dilihat menggunakan bantuan mikroskop (Budi Utomo, 2005)

4. Kadar debu total

Dalam Environmental Protection department (EPG, 2006) disebutkan kadar debu total atau juga dikenal sebagai partikulat tersuspensi total (TSP) mengacu pada semua partikel di atmosfer. Kadar debu total merupakan partikel di udara yang memiliki diameter kurang dari $100 \mu \mathrm{m}$ (micrometer). Di antara kadar debu total, termasuk partikel yang dapat terhisap oleh sistem pernapasan. Partikel ini merupakan partikel di atmosfer yang memiliki ukuran sama dengan atau bahkan kurang dari $10 \mu \mathrm{m}$.

Beberapa mekanisme tertimbunnya debu dalam paru menurut Suma'mur (2009) antara lain:

a. Inertia

Inertia terjadi pada waktu udara membelok ketika melalui jalan pernafasan yang tidak lurus, maka partikel debu yang bermassa cukup besar tidak dapat membelok mengikuti aliran udara, melainkan terus dan akhirnya menumbuk selaput lendir dan mengendap disana.

b. Sendimentasi

Sendimentasi merupakan penimbunan debu yang terjadi di bronkhi dan bronkhioli, sebab ditempat itu kecepatan udara sangat kurang kira - kira $1 \mathrm{~cm} /$ detik sehingga gaya tarik dapat bekerja terhadap partikel debu dan mengendapnya.

c. Gerakan Brown

Gerakan Brown merupakan penimbunan dari partikel yang berukuran sekitar atau kurang dari 0,1 mikron. Partikel yang kecil ini digerakan oleh gerakan Brown sehingga ada kemungkinan membentur permukaan alveoli dan hinggap disana.

Pencemaran Udara

Udara menurut Kamus Besar Indonesia (KBBI, 2012), udara adalah campuran berbagai gas yang tidak berwarna dan tidak berbau yang memenuhi ruang diatas bumi seperti yang kita hirup apabila kita bernafas.

Pencemaran udara menurut Peraturan Menteri Negera Lingkungan Hidup Nomor 12 tahun 2010 Tentang Pelaksanaan Pengendalian Pencemaran Udara di Daerah adalah masuknya atau dimasukkannya zat energi, dan/atau komponen lain ke dalam udara ambien oleh kegiatan manusia, sehingga melampaui baku mutu udara yang telah ditetapkan.

Sistem Pernafasan

Urutan saluran pernapasan adalah sebagai berikut: rongga hidung $>$ faring $>$ trakea $>$ bronkus $>$ paru-paru (bronkiolus dan alveolus).

Proses pernapasan pada manusia dimulai dari hidung. Udara yang diisap pada waktu menarik nafas (inspirasi) biasanya masuk melalui lubang hidung (nares) kiri dan kanan selain melalui mulut.Pada saat masuk, udara disaring oleh bulu hidung yang terdapat di bagian dalam lubang hidung.

Pada waktu menarik napas, otot diafragma berkontraksi.Semula kedudukan diafragma melengkung keatas sekarang menjadi lurus sehingga rongga dada menjadi mengembang.Hal ini disebut pernapasan perut.Bersamaan dengan kontraksi otot diafragma, otot-otot tulang rusuk juga berkontraksi sehingga rongga dada mengembang.Hal ini disebut pernapasan dada.

Akibat mengembangnya rongga dada, maka tekanan dalam rongga dada menjadi berkurang, sehingga udara dari luar masuk melalui hidung selanjutnya melalui saluran pernapasan akhirnya udara masuk ke dalam paru-paru, sehingga paru-paru mengembang.

Setelah melewati rongga hidung, udara masuk ke kerongkongan bagian atas (naro-pharinx) lalu kebawah untuk masuk tenggorokan (larynx).

Setelah melalui tenggorokan, udara masuk ke batang tenggorok atau trachea, dari sana diteruskan ke saluran yang bernama bronchus atau bronkus. Saluran bronkus ini terdiri dari beberapa tingkat percabangan dan akhirnya berhubungan di alveolus di paru-paru.

Udara yang diserap melalui alveoli akan masuk ke dalam kapiler yang selanjutnya dialirkan ke vena pulmonalis atau pembuluh balik paru-paru. Gas oksigen diambil oleh darah. Dari sana darah akan dialirkan ke serambi kiri jantung dan seterusnya. 
Selanjutnya udara yang mengandung gas karbon dioksida akan dikeluarkan melalui hidung kembali. Pengeluaran napas disebabkan karena melemasnya otot diafragma dan otototot rusuk dan juga dibantu dengan berkontraksinya otot perut.Diafragma menjadi melengkung ke atas, tulang-tulang rusuk turun ke bawah dan bergerak ke arah dalam, akibatnya rongga dada mengecil sehingga tekanan dalam rongga dada naik.Dengan naiknya tekanan dalam rongga dada, maka udara dari dalam paru-paru keluar melewati saluran pernapasan.

Ringkasan jalannya Udara Pernapasan:

1. Udara masuk melalui lubang hidung

2. melewati nasofaring

3. melewati oral farink

4. melewati glotis

5. masuk ke trakea

6. masuk ke percabangan trakea yang disebut bronchus

7. masuk ke percabangan bronchus yang disebut bronchiolus

8. udara berakhir pada ujung bronchus berupa gelembung yang disebut alveolus (jamak: alveoli). (Hedisasrawan, 2013)

Petugas Kebersihan

Petugas kebersihan di Kabupaten Banyumas khususnya Kota Purwokerto (UKP Purwokerto) terdapat pekerja PNS, PHL, dan PTT.Jumlah pekerja petugas kebersihan penyapu, angkutan, dan pengemudi berjumlah 247, Ka. UKP, kasubag TU, staf, mandor, penarik retribusi, dan penjaga berjumlah 17, jadi total karyawan petugas pekerja kebersihan adalah 264. Khusus pekerja petugas kebersihan penyapu adalah 107. Petugas kebersihan penyapu jalan bekerja secara tersebar khususnya di Kota Purwokerto batas kota selatan timur yaitu Margono dan batas barat yaitu karang welas. setiap pekerja harus menyapu jalan 1000-1500 M. Bekerja dengan sistem shift yaitu shift pagi mulai dari jam 05:00-12:00 WIB, shift siang jam 12:00-19:00 WIB, dan shift malam 19:00-24:00 WIB. Umur pekerja PNS berumur 33 Th- 58 Th, PHL dan PTT berumur 18 Th-32 Th. lama petugas kebersihan bekerja yaitu PNS sampai pensiun, PHL 3 bulan sekali melakukan perpanjangan, dan PTT 2 tahun sekali melakukan perpanjangan waktu, setelah masa bekerja habis dilakukan perpanjangan waktu dan ada beberapa perkerja yang bergantian tugas.

\section{Metode}

Jenis penelitian yang digunakan merupakan penelitian observasional analitik dengan penelitian Cross Sectional, dengan pendekatan observasi atau pengumpulan data dalam satu waktu (point time approach).Artinya tiap subyek penelitian hanya diobservasi sekali saja dan pengukuran dilakukan terhadap status karakter atau variabel pada saat pemeriksaan.

Populasi dalam penelitian adalah petugas kebersihan di Kota Purwokerto berjumlah 247 petugas kebersihan yang diteliti 80 responden. Sampel yang diambil semua petugas kebersihan yang PNS dengan total 80 responden.Analisis univariat untuk mendeskripsikan karakteristik responden dan faktor risiko penurunan kapasitas paru, dilakukan dengan menyajikan distribusi variabel yang diteliti (mean dan standar deviasi) dan disajikan dalam bentuk tabel untuk mengetahui proposi masing-masing variabel.

Analisis Bivariat untuk mengetahui apakah variabel bebas dan variabel terikat ada hubungannya dengan tabulasi saling menggunakan Chi Square.

Keputusan yang diambil dalam uji Chi Squareadalah :

$$
\mathrm{X}^{2}=\sum \frac{(O-E)^{2}}{E}
$$

Keterangan :

$\chi^{2}=$ Chi Squares hitung

$\mathrm{O}=$ Frekuensi Observasi (Observed)

$\mathrm{E}=$ Frekuensi Harapan (Expected)

Keputusan yang diambil dalam uji chi-square adalah:

a) Bila nilai $\mathrm{p}>0,05$ maka tidak ada hubungan antara variabel dependen dengan variabel independen (Ho diterima, Ha ditolak)

b) Bila nilai $\mathrm{p}<0,05$ maka ada hubungan yang signifikan atara variabel dependen dengan variabel independen (Ho ditolak, Ha diterima)

Interpretasi hasil OR:

OR $>1$ dengan tingkat kepercayaan 95\% dan tidak melewati 1 , maka variabel yang diduga menjadi faktor risiko merupakan faktor risiko terjadinya penyakit.

OR > 1 dengan tingkat kepercayaan 95\% dan melewati 1 , maka variabel yang diduga menjadi faktor risiko bukan merupakan faktor risiko terjadinya penyakit.

$\mathrm{OR}=1$, maka variabel yang diduga menjadi faktor risiko bukan merupakan faktor risiko terjadinya penyakit.

OR $<1$ dengan tingkat kepercayaan 95\% dan tidak melewati 1 , maka variabel yang diduga menjadi 
faktor risiko merupakan faktor protektif yang dapat mengurangi terjadinya penyakit

OR $<1$ dengan tingkat kepercayaan 95\% dan melewati 1 , maka variabel yang diduga menjadi faktor risiko belum tentu merupakan faktor protektif yang dapat mengurangi terjadinya penyakit.

\section{Hasil}

\section{A. Gambaran umum Kabupaten Banyumas}

Luas wilayah Kabupten Banyumas sekitar 1.327, $60 \mathrm{~km}^{2}$ atau setara dengan 132.759,56 ha, dengan keadaan geografis daratan dan pegunungan dengan struktur pgunungan terdiri dari sebagian lembah Sungai Serayu untuk pertanian, sebagian dataran tinggi untuk pemukiman dan pekarangan, dan sebagian pegunungan untuk perkebunan dan hutan tropis yang terletak dilereng Gunung Slamet sebelah selatan. Keadaan cuaca dan iklim di Kabupaten Banyumas memiliki iklim tropis basah. Batas wilayah Kabupaten Banyumas :

Sebelah utara: Gunung Slamet, Kabupaten Tegal dan Kabupaten Pemalang

Sebelah Selatan: Kabupaten Cilacap

Sebalah Barat: Kabupaten Cilacap dan Kabupaten Brebes

Sebelah Timur : Kabupaten Purbalingga, Kebumen, dan Banjarnegara

Jumlah penduduk Kabupaten Banyumas 1.578.129 jiwa. Pendidikan yang berada di Kabupaten Banyumas TK 679 unit, SD atau MI 1.167 unit, SMP atau MTs 218 unit, SMA atau MA 53 unit, dan perguruan tinggi 2 unit. Mata pencaharian sebagian besar adalah petani dan PNS.

B. Gambaran umum Unit Kebersihan dan Pertamanan (UKP) Purwokerto

Kantor kebersihan dan pertamanan di Kota Purwokerto merupakan salah satu UKP di Kelurahan Mersi, Kecamatan Purwokerto Tmur, Kabupaten Banyumas. Jarak dari Ibu Kota Kabupaten kurang lebih 7 km ke arah Barat. Jumlah penduduk di Kota Purwokerto kurang lebih 428.077 jiwa yang tersebar di berbagai wilayah Kecamatan yang ada di Kota Purwokerto. Luas Kota Purwokerto kurang lebih 3.585,34 ha, dengan kondisi geografis pemukiman dan perkebunan. Kondisi curah hujan bulan April 2017 antara 201-300 mm, dan bagian Banyumas Utara 301-400 mm.

\section{Profil petugas kebersihan}

Petugas kebersihan di Kota Purwokerto bekerja selama 7 jam/hari memiliki risiko terpapar debu, oleh partikel fisik dan kimia yang berasal dari pembakaran bahan minyak dari kendaraan. Jumlah pekerja 247 orang, dengan jam kerja pagi, jam 05:00-12:00 WIB, siang 12:00-19.00 WIB, dan malam 19:00-24:00 WIB. Jarak pekerja kebersihan satu dengan yang lainnya 1000-1500 meter.

\section{Data Univariat}

Penelitian ini diperoleh dari hasil studi pendahuluan yang dilakukan secara cross sectional terhadap 247 petugas kebersihan. Pengukuran kapasitas paru dilakukan oleh peneliti di kantor UKP Purwokerto yang berada di Mersi yang dilakukan selama 3 hari.

1. Distribusi kapasitas paru responden

Hasil pengukuran kapasitas paru responden yang PPOK jumlah $74(92,5)$ petugas kebersihan dan petugas kebersihan yang tidak PPOK sebanyak 6 $(7,5)$ petugas sehingga dapat dikatakan rata-rata responden memiliki kelainan kapasitas paru yang PPOK. Data selengkapnya pada tabel 4.1

Tabel 4.1 Distribusi RespondenBerdasarkan Kapasitas Paru

\begin{tabular}{llll}
\hline No & Kapasitas Paru & Jumlah & $\%$ \\
\hline 1 & PPOK & 74 & 92.5 \\
2 & Tidak POOK & 6 & 7.5 \\
\hline & Total & 80 & 100.0 \\
\hline
\end{tabular}

2. Distribusi umur responden

Karakteristik umur responden sebagian besar antara 20 sampai dengan 60 tahun. Sebagian besar responden berumur 41-46 tahun 93,8 \%, umur termuda 26 tahun dan tertua 57 tahun dengan standar deviasi 0,244 . Data selengkapnya dapat dilihat pada tabel 4.2

Tabel 4.2 Distribusi Responden

\begin{tabular}{llll} 
& & \multicolumn{3}{c}{ Berdasarkan Umur } \\
\hline No & Umur & Jumlah & $\%$ \\
\hline 1 & $20-40$ & 5 & 6,3 \\
2 & $41-60$ & 75 & 93,8 \\
\hline
\end{tabular}




$\begin{array}{lll}\text { Total } & 80 & 100.0\end{array}$

3. Distribusi perilaku merokok

Hasil survey peneliti wawancara dengan petugas kebersihan ternyata lebih banyak yang merokok dengan jumlah 58 (72,5\%), sedangkan petugas kebersihan yang tidak merokok dengan jumlah 22 (27,5\%). Data selengkapnya dapat dilihat pada tabel 4.3.

Tabel 4.3 Distribusi Responden Perilaku Merokok

\begin{tabular}{llll}
\hline No & Perilaku Merokok Jumlah & $\%$ \\
\hline 1 & Ya & 58 & 72,5 \\
2 & Tidak & 22 & 27,5 \\
\hline & Total & 80 & 100.0 \\
\hline
\end{tabular}

4. Distribusi Perilaku memakai masker

Hasil penelitian responden yang memakai alat pelindung diri masker 20 petugas kebersihan (25,0\%), sedangkan yang tidak memakai 60 (75,0\%). Data selengkapnya dapat dilihat pada tabel 4.4.

Tabel 4.4 Distribusi Responden Perilaku Memakai Masker

\begin{tabular}{llll}
\hline No & $\begin{array}{l}\text { Perilaku Memakai } \\
\text { masker }\end{array}$ & Jumlah & $\%$ \\
\hline 1 & Tidak & 60 & 75,0 \\
2 & Ya & 20 & 25,0 \\
\hline & Total & 80 & 100.0 \\
\hline
\end{tabular}

5. Suhu $\left({ }^{\circ} \mathrm{C}\right)$ dan Kelembaban (\%)

Tabel 4.5 Distribusi Suhu Dan Kelembaban Lingkungan

\begin{tabular}{|c|c|c|c|}
\hline No & $\begin{array}{l}\text { Titik } \\
\text { Pengukuran }\end{array}$ & $\begin{array}{l}\text { Suhu } \\
\left({ }^{0} \mathrm{C}\right)\end{array}$ & $\begin{array}{l}\text { Kelembaban } \\
\text { (\%) }\end{array}$ \\
\hline 1 & $\begin{array}{l}\text { Rumah Sakit } \\
\text { Margono }\end{array}$ & 26,5 & 76 \\
\hline 2 & Tanjung & 33 & 60 \\
\hline 3 & $\begin{array}{l}\text { Universitas } \\
\text { Jendral } \\
\text { Soedirman }\end{array}$ & 30,25 & 78 \\
\hline 4 & $\begin{array}{l}\text { Alun-alun } \\
\text { Purwokerto }\end{array}$ & 31 & 77 \\
\hline 5 & KarangLewas & 36 & 42 \\
\hline
\end{tabular}

6. Data kadar debu (PDS) dan debu lingkungan (TS)

Tabel 4.6 Distribusi Kadar Debu PDS dan Debu Lingkungan TSP

\begin{tabular}{llll}
\hline No & $\begin{array}{l}\text { Titik } \\
\text { Pengukuran }\end{array}$ & PDS $\left(\mathrm{mg} / \mathrm{m}^{3}\right)$ & TSP $\left({ }^{0} \mathrm{C}\right)$ \\
\hline 1 & $\begin{array}{l}\text { Rumah Sakit } \\
\text { Margono }\end{array}$ & 26,5 & 76 \\
2 & $\begin{array}{l}\text { Tanjung } \\
\text { Universitas }\end{array}$ & 33 & 60,25 \\
3 & $\begin{array}{l}\text { Jendral } \\
\text { Soedirman }\end{array}$ & 78 \\
4 & $\begin{array}{l}\text { Alun-alun } \\
\text { Purwokerto }\end{array}$ & 31 & 77 \\
5 & $\begin{array}{l}\text { Karang } \\
\text { Lewas }\end{array}$ & 36 & 42 \\
\hline
\end{tabular}

\section{E. DataBivariat}

Analisis bivariat dimaksudkan untuk mengetahui hubungan antara variabel umur, perilaku merokok, perilaku memakai masker (variabel independent) berisiko dengan kelainan kapasitas paru (variabel dependent), dengantingkat kemaknaan 95\%. Adanya hubungan antara variabel independent dengan penurunan kapasitas paru ditunjukan dengan nilai $\mathrm{p}<0,05$. Secara lengkap seperti pada tabel berikut ini.

1. Umur responden dengan kapasitas paru Umur responden dikategorikan menjadi kurang dari 40 tahun dan lebih dari 40 tahun. Proporsi umur kurang dari 40 tahun 5 orang dengan kategori semua PPOK sedangkan umur lebih 40 tahun 75orang, dengan kategori 69 PPOK dan 6 tidak PPOK. Diperoleh nilai $\rho=1,000$. Data selengkapnya dapat dilihat pada tabel 4.7.

Tabel 4.7 Hubungan Umur Dengan Kapasitas Paru

\begin{tabular}{|c|c|c|c|c|c|}
\hline \multirow[t]{2}{*}{ No } & \multirow[t]{2}{*}{$\begin{array}{l}\text { Rentang } \\
\text { Umur } \\
\text { Responden }\end{array}$} & \multicolumn{2}{|c|}{$\begin{array}{l}\text { Kapasitas Paru } \\
\text { Petugas } \\
\text { Kebersihan }\end{array}$} & \multirow[t]{2}{*}{ Total } & Nilai $\rho$ \\
\hline & & PPOK & $\begin{array}{l}\text { Tidak } \\
\text { PPOK }\end{array}$ & & 1,000 \\
\hline 1 & $\begin{array}{l}\text { Kurang dari } \\
40\end{array}$ & 5 & 0 & 5 & \\
\hline 2 & $\begin{array}{l}\text { Lebih dari } \\
40\end{array}$ & 69 & 6 & 75 & \\
\hline & Total & 74 & 6 & 80 & \\
\hline
\end{tabular}

2. Perilaku merokok dengan kapasitas paru Proporsi responden perilaku merokok dikategorikan menjadi tidak merokok dan merokok. Petugas kebersihan yang merokok 58 dengan kategori 52 PPOK dan 6 tidak PPOK, yang 
tidak merokok 22 orang dengan kategori semua PPOK. Diperoleh nilai $\rho=0,180$. Data selengkapnya dapat dilihat pada tabel 4.8

Tabel 4.8 Hubungan Perilaku Merokok Dengan Kapasitas Paru

\begin{tabular}{|c|c|c|c|c|c|}
\hline \multirow[t]{2}{*}{ No } & \multirow[t]{2}{*}{$\begin{array}{l}\text { Perilaku } \\
\text { Merokok }\end{array}$} & \multicolumn{2}{|c|}{$\begin{array}{l}\text { Kapasitas Paru } \\
\text { Petugas } \\
\text { Kebersihan }\end{array}$} & \multirow[t]{2}{*}{ Total } & Nilai $\rho$ \\
\hline & & PPOK & $\begin{array}{l}\text { Tidak } \\
\text { PPOK }\end{array}$ & & 1,180 \\
\hline 1 & $\mathrm{Ya}$ & 52 & 6 & 58 & \\
\hline \multirow[t]{2}{*}{2} & Tidak & 22 & 0 & 22 & \\
\hline & Total & 74 & 6 & 80 & \\
\hline
\end{tabular}

3. Perilaku memakai masker dengan kapasitas paru

Perilaku memakai masker dikategorikan menjadi tidak memakai masker dan memakai masker.Petugas kebersihan yang tidak memakai masker 60 dengan kategori 56 PPOK dan 4 tidak PPOK, sedangkan yang memakai masker 20 orang dengan kategori 18 PPOK dan 2 tidak PPOK. Diperoleh nilai $\rho=0,637$. Data selengkapnya dapat dilihat pada tabel 4.9

Tabel 4.9 Hubungan Perilaku Memakai Masker

\begin{tabular}{|c|c|c|c|c|c|}
\hline \multirow{6}{*}{ No } & \multicolumn{5}{|c|}{ Dengan Kapasitas Paru } \\
\hline & \multirow{5}{*}{$\begin{array}{l}\text { Perilaku } \\
\text { Memakai } \\
\text { Masker }\end{array}$} & \multirow{3}{*}{\multicolumn{2}{|c|}{$\begin{array}{l}\text { Kapasitas Paru } \\
\text { Petugas } \\
\text { Kebersihan }\end{array}$}} & \multirow[t]{5}{*}{ Total } & \multirow[t]{3}{*}{ Nilai $\rho$} \\
\hline & & & & & \\
\hline & & & & & \\
\hline & & PPOK & Tidak & & \multirow[t]{5}{*}{0,637} \\
\hline & & & PPOK & & \\
\hline 1 & $\mathrm{Ya}$ & 56 & 4 & 60 & \\
\hline \multirow[t]{2}{*}{2} & Tidak & 18 & 2 & 20 & \\
\hline & Total & 74 & 6 & 80 & \\
\hline
\end{tabular}

\section{Pembahasan}

1. Jenis kelamin

Jumlah petugas kebersihan terdiri dari 77 laki-laki dan 3 perempuan. Data tersebut menunjukkan bahwa proporsi laki-laki lebih besar dibanding perempuan. Keadaan ini dimungkinkan karena pekerja sebagai petugas kebersihan merupakan pekerja lapangan diluar gedung, dengan membutuhkan tenaga fisik yang besar sehingga hasil pekerja dapat maksimal.

2. Umur responden

Data responden menurut umur adalah paling muda umur 26 tahun dan yang tertua 57 tahun, dengan rata-rata 32 tahun. Umur responden dikategorikan menjadi kurang dari 40 tahun 5 orang dan lebih dari 40 tahun 75 orang. Melihat dari data umur tersebut rata-rata umur pekerja termasuk dalam umur produktif yaitu 20-50 tahun, dengan umur yang produktif maka pekerjaan dapat diselesaikan dengan baik. Jika dihubungkan dengan kapasitas paru maka kelompok umur kurang dari 40 tahun yang dikategorikan semua PPOK 5 orang sedangkan kelompok umur lebih dari 40 tahun dikategorikan PPOK 69 orang dan tidak PPOK 6 orang.

Hasil perhitungan statistik diperoleh nilai $\rho=1,000$. Sehingga dapat disimpulkan bahwa tidak ada hubungan antara umur petugas kebersihan dengan status kapasitas paru. Hal ini disebabkan karena jumlah pekerja hampir semuanya termasuk dalam usia produktif. Sedangkan dilihat dari tabel silang terdapat nilai $\rho=1,000$. H0 diterima yang berarti tidak ada hubungan antara umur dengan kejadian PPOK.

Hasil penelitian ini berbeda dengan penelitian Budi Utomo (2005) dengan kategori umur lebih dari 35 tahun disimpulkan bahwa ada hubungan yang signifikan antara umur dengan kapasitas paru, hasil analisis menunjukan bahwa semakin tua umur semakin besar risiko terjadinya penurunan kapasitas paru dengan nilai $\rho=0,001$, dimana besar risikonya 3,3 kali (OR=3,3 ; 95\% CI=1,6-7,1). Hasiil penelitian ini sama seperti dengan penelitian Fitra Nursyahbani Luthfiah (2011) dengan gangguan fungsi paru pada pekerja dengan nilai $\rho$-value $=0,588$.

Umur mmerupakan faktor risiko kejadian gangguan fungsi paru atau semakin tua usia pekerja maka semakin tinggi risiko yang dimiliki untuk mengalami kejadian gangguan fungsi paru. Bahwa umur akan cenderung mempengaruhi daya tahan tubuh terhadap kejadian suatu penyakit . kian bertambah umur seseorang akan kian menurun pula daya tahan tubuh seseorang, dengan demikian menjadi tua adalah suatu proses menghilangnya secara perlahan-lahan kemampuan jaringan untuk memperbaiki diri, atau mengganti dan mempertahankan struktur darii fungsi normalnya (Nugraheni, 2004). Sirait (2010) menyatakan bahwa penderita yang mengalami gangguan paru ditemukan paling banyak pada kelompok umur produktif 15-44 tahun. Hal ini terjadi kareana pada usia produktif mempunyai mobilitas yang tinggi sehingga kemungkinan untuk terpapar kuman lebih besar dan ditambah 
kebiasaan pekerja yang mempunyai faktor risiko untuk mengalami gangguan pernapasan seperti : merokok, minum alkohol, begadang dan yang lainnya.

\section{Perilaku merokok}

Data responden menurut perilaku merokok adalah responden yang merokok 58 orang dan 22 orang tidak merokok. Perilaku merokok dikategorikan menjadi merokok dan tidak merokok. Melihat dari data perilaku merokok tersebut rata-rata perilaku merokok pekerja termasuk dalam kelompok yang rentan dengan terpaparnya partikel debu, dengan perilaku tidak merokok petugas kebersihan akan menjadi tidak terpapar oleh partikel dan zat beracun yang terkandung dalam rokok. Sehingga pekerja menjadi lebih sehat dan dapat menghasilkan pekerjaan yang baik. Jika dihubungkan dengan kapasitas paru maka kelompok perilaku merokok lebih banyak yang merokok yaitu 58 orang dengan kategori PPOK 52 sedangkan 6 tidak PPOK, sedangkan yang tidak merokok 22 orang dengan kategori semua tidak PPOK.

Hasil perhitungan statistik diperoleh nilai $\rho=0,180$. Sehingga dapat disimpulkan bahwa tidak ada hubungan antara perilaku merokok petugas kebersihan dengan status kapasitas paru. Hal ini disebabkan karena jumlah pekerja hampir semuanya termasuk perokok. Sedangkan dilihat dari tabel silang terdapat nilai $\rho=0,180$. H0 diterima yang berarti tidak ada hubungan antara perilaku merokok dengan kejadian PPOK.

Hasil penelitian ini berbeda dengan penelitian Budi Utomo (2005) dengan penurunan kapasitas paru. (perokok ringan $\rho=$ 0,037 dan perokok sedang $\rho=0,000$ ). Demikian juga jika dilihat dari nilai odds rationya, ternyata kebiasaan merokok merupakan faktor risiko terjadinya penurunan kapasitas paru. Faktor risiko perokok sedang 2,8 kali $(\mathrm{CI}=2,764-24,836)$ dan perokok ringan 2,9 kali (CI $=1,2-6,9)$ dan $\rho=0,140$. Hasil penelitian ini sama seperti dengan penelitian Fitra Nursyahbani Luthfiah (2011) dengan gangguan fungsi paru pada pekerja dan diperoleh nilai $\rho$-value $=0,692$.

Kebiasaan merokok dapat menyebabkan perubahan struktur dan fungsi salurran nafas serta jaringan paru-paru. Akibat perubahan anatomi saluran nafas pada perokok akan menimbulkan penurunan pada fungsi paru-paru (Muis et al. 2008). Menurut Meita (2012), kebiasaan merokok dapat menimbulkan gangguan ventilasi paru karena dapat menyebabkan iritasi dan sekresi mukus yang berlebihan pada bronkus.

4. Perilaku memakai masker

Data responden menurut perilaku memakai masker adalah responden yang tidak memakai masker 60 orang dan 20 orang memakai masker. Perilaku memakai masker dikategorikan menjadi tidak memakai masker dan memakai masker. Melihat dari data perilaku memakai masker tersebut rata-rata perilaku memakai masker pekerja termasuk dalam kelompok yang rentan terpaparnya partikel debu, dengan perilaku memakai masker petugas kebersihan akan menghasilkan pekerjaan yang baik. Jika dihubungkan dengan kapasitas paru maka kelompok perilaku memakai masker lebih banyak yang tidak menggunakan masker yaitu 60 orang dengan kategori PPOK 56 sedangkan 4 tidak PPOK, sedangkan yang memakai masker 20 orang dengan kategori 18 PPOK dan 2 tidak PPOK.

Hasil perhitungan statistik diperoleh nilai $\rho=0$, 637. Sehingga dapat disimpulkan bahwa tidak ada hubungan antara perilaku memakai masker petugas kebersihan dengan status kapasitas paru. Hal ini disebabkan karena jumlah pekerja hampir semuanya termasuk tidak meggunakan masker. Sedangkan dilihat dari tabel silang terdapat nilai $\rho=0,637$. H0 diterima yang berarti tidak ada hubungan antara perilaku memakai masker dengan kejadian PPOK.

Hasil penelitian ini berbeda dengan penelitian Budi Utomo (2005) dengan hasil analisis bivariat menunjukan bahwa ada hubungan yang bermakna kebiasaan memakai masker dengan penurunan kapasitas paru (tidak pernah memakai masker $\rho=0,000$ dan kadangkadang memakai masker $\rho=0,0042$ ). Sedangkan dilihat dari besarnya risiko, kebiasaan tidak pernah memakai masker mempunyai risiko 5 kali $(\mathrm{OR}=4,9$; $\mathrm{CI}=2,1-$ 11,5), dan kadang - kadang memakai masker mempunyai risiko 2,7 kali (OR = 2,7; CI = 1,07,2 ) untuk terjadinya penurunan kapasitas paru. Hasil penelitian ini sama seperti dengan penelitian Fitra Nursyahbani Luthfiah (2011) menunjukan hasil analisis statistik tidak ada hubungan antara kebiasaan memakai masker ketika bekerja dengan gangguan (penurunan) fungsi paru pada pekerja (baik pada kelompok pekerja yang selalu memakai APD, kadang- 
kadang, maupun tidak pernah memakai dengan nilai $\rho$-value masing-masing kelompok 0,797 ; 0,501; 0,999).

Menurut Ramadan (2009) sampai saatt ini masih ada tenaga yang menganggap pemakaian APD mengganggu tenaga kerjanya dan efek perlindungannya kurang. Perilaku pemakaian APD dipengaruhi oleh pengetahuannya dan sikap dari pekerja yanng tercemin dari tidakannya.

\section{Keterbatasan Penelitian}

Dalam penelitian ini, peneliti memiliki beberapa keterbatasan yaitu :

1. Pada saat peneliti melakukan penelitian musim hujan sehingga mempengaruhi kadar debu yang diukur. Hujan cenderung melarutkan bahan polutan yang terdapat dalam udara sehingga dapat membersihkan atmosfer karena polutan mengendap lebih cepat.

2. Jenis penelitian yang digunakan adalah cross sectional, sehingga hasilnya hanya mengggambarkan keadaan sesaat, dan diperlukan jumlah sampel yang lebih besar dari $>100$.

3. Hasil statistik tidak diketahui hubungan antara variabel independen dengan variabel dependen karena data yang tidak menderita PPOK 6 orang ( 7,5\% ) sehingga cell kurang dari $5 \%$.

\section{Simpulan}

a. Hasil pengukuran kapasitas paru 74 orang (92,5\%) penyakit paru obstruktif kronik dan 6 orang (7,5\%) tidak mempunyai Penyakit Paru Obstruktif Kronik (PPOK).

b. Karakteristik responden umur 26-57 tahun, 58 orang $(72,5 \%)$ perokok dan 22 orang $(27,5 \%)$ tidak merokok, perilaku memakai masker 60 orang $(75,0 \%)$ tidak menggunakan masker, sedangkan yang memakai masker 20 orang (25,0\%).

c. Umur responden kurang dari 40 tahun 5 orang (6,25\%), dengan kategori semua mempunyai Penyakit Paru Obstruktif Kronik (PPOK).Umur lebih dari 40 tahun 75 orang (93,75\%), dengan kategori 69 orang (86,25\%)mempunyai Penyakit Paru Obstruktif Kronik (PPOK) dan 6 orang (7,5\%) tidak PPOK. Tidak ada hubungan antara umur dengan penyakit paru obstruktif kronik $\rho=1,000$.

d. Perilaku merokok petugas kebersihan yang merokok 58 orang (72,5\%), dengan kategori 52 orang (65\%) PPOK dan 6 orang (7,5\%) tidak mempunyai Penyakit Paru Obstruktif Kronik (PPOK).Sedangkan tidak merokok 22 orang (27,5\%), dengan kategori semua mempunyai Penyakit Paru Obstruktif Kronik (PPOK). Tidak ada hubungan antara perilaku merokok dengan penyakit paru obstruktif kronik $\rho=0,180$.

e. Perilaku memakai masker petugas kebersihan yang tidak memakai masker 60 orang (75\%), dengan kategori 56 mempunyai Penyakit Paru Obstruktif Kronik (PPOK) dan 4 orang (5\%) tidak mempunyai Penyakit Paru Obstruktif Kronik(PPOK). Memakai masker 20 orang (25\%), dengan kategori 18 orang (22,5\%) mempunyai Penyakit Paru Obstruktif Kronik(PPOK) dan 2 orang (2,5 \%) tidak mempunyai Penyakit Paru Obstruktif Kronik(PPOK). Tidak ada hubungan antara perilaku memakai masker dengan penyakit paru obstruktif kronik $\rho=0,637$.

\section{Saran}

1. Dinas Lingkungan Hidup Banyumas

a. Melaksanakan penyuluhan tentang pentingnya memakai alat pelindung diri, terutama masker.

b. Melakukan pengukuran kapasitas paru secara berkala yang melakukan petugas dinas kesehatan.

2. Kepala Unit Kebersihan dan Pertamanan (UKP) Purwokerto

a. Perlu menyediakan fasilitas masker yang memenuhi syarat

b. Menegaskan kepada petugas kebersihan pada saat bekerja untuk tidak merokok agar hasil pekerjaannya maksimal.

3. Petugas kebersihan di Kota Purwokerto

a. Perlu adanya upaya meningkatkan perilaku memakai masker dalam melakukan pekerjaan.

b. Menghentikan atau mengurangi perilaku merokok pada saat melakukan pekerjaan

4. Peneliti lanjutan

a. Besar sampel dapat lebih ditingkatkan

b. Jenis penelitian menggunakan case control dengan analisis chi square, setelah itu dilanjutkan mencari faktor risiko.

\section{Daftar Pustaka}

Alya Mutiara Basti, Kadar Debu Total dan Gejala ISPA Ringan Pada Pekerja Departemen Pemintalan Di Industri Tekstil PT UNITEX, 
Tbk Bogor, Universitas Islam Negeri Syarif Hidayatullah, Jakarta : 2014

Bahar, A., 2003, Evaluasi Prabedah Pasien Penyakit Paru Obstruktif Kronik.

Budi Utomo, 2015, Faktor-Faktor Risiko Penurunan Kapasitas paru pekerja tambang batu Kapur, Ajibarang

DAPODIK, 2016, Data Pokok Pendidikan, Banyumas.

Depkes RI, 2003, Pencemaran Udara.

Depkes RI, 2008, Penyakit Paru Obstruktif Kronik, Jakarta.

Dinas Lingkungan Hidup, 2017, Data Karyawan UKP wilayah Purwokerto, Banyumas.

Djamaluddin Ramlan, Penulisan Penelitian Eksplanatif, Purwokerto, Universitas Jendral Sudirman Purwokerto ; 2014

Fitra Nursyahbani Lutfhiah, 2011, Faktor- Faktor Yang Berhubungan Dengan Gangguan Fungsi Paru Pada Pekerja Industri Kapur, Padalarang

Global, 2011, Studi 12 Negara Asia Pasifik.

H. J. Mukono, 2010, Faktor Risiko Penurunan Penyakit Paru Obstruktif Kronik.

Hedisasrawan, 2013, Proses Pernafasan.

KBBI, 2012, Kamus Besar Bahasa Indonesia, Kamus versi online dalam jaringan.Kementrian Pendidikan dan Budaya. Tersedia di : fttp;//kbbi.web.id/udara

Khader, 2007, Penurunan Kadar Oksigen.

Meita AC. 2012. Hubungan Paparan Debu dengan Kapasitas Penyapu Pasar Johar Kota Semarang. Jurnal Kesehatan Masyarakat. Vol. 1 (No.2) : Hal 657-659.

Mengkidi, Dorce, 2006, Gangguan Fungsi Paru dan Faktor-Faktor Yang Mempengaruhi Pada Karyawan PT Semen Tonasa Pangkep Sulawesi Selatan. Tesis, Program Pascasarjana Kesehatan Lingkungan Industri, Universitas Diponegoro Semarang.

Muis M., SyamsiarvR., Arifah R. 2008. Studi Kapasitas Paru Pada Karyawan Departemen Produksi Semen PT. Semen Tonasa Pangkep. Jurnal MKMl. Vol. 4 (No.1) Hal 41

Mukono, 2010, Prinsip Dasar Kesehatan Lingkungan, Surabaya : Airlangga University Press.

Nugraheni, FS. 2004. Analisis Faktor Risiko Kadar Debu Organik Di Udara Terhadap Gangguan Fungsi Paru Pada Pekerja Industri Penggilingan Padi di Demak. Tesis Universitas Diponegoro Semarang.

Peraturan Menteri Negara Lingkungan Hidup Nomor 12 Tahun 2010 Tentang Pelaksanaan Pengendalian Pencemaran Udara Di Daerah
Perhimpunan Dokter Paru Indonesia, Pedoman Diagnosis dan Penatalaksanaan di Indonesia, 2003

Ramadan. 2008. Gambaran Perilaku Pemakaian Masker dan Pengukuran Kadar Debu Pada Pekerja Bagian Bongkar Karet Kering Instalasi Bengawan PTPN III tahun 2008. Skripsi. Medan: FKM USU.

Sirait, M. Hubungan Karakteristik Pekerja dengan Faal Paru di Kilang Padi Kecamatan Porsea tahun 2010. Skripsi Universitas Sumattera Utara.

Suma'mur PK,2009, Kesehatan Kerja dan Pencegahan Kecelakaan, Jakarta: Gunung Agung.

Syamsudin, 2003, Hubungan Kualitas Udara dan Terjadinya penyakit Paru Obstruktif Kronik Pada Pengrajin Tembaga di Kecamatan Cepogo, Kabupaten Boyolali : UGM.

Tarlo, Susan M, dkk, 2010, Occupational and Environmental Disease, UK Wiley Blackwell Press

UKP Purwokerto, 2016, Profil Petugas Kebersihan.

US, Census Bereau, 2012, Laporan Ekstrapolasi Data Statistik dan Data Base Internasional.

WHO, 2012, Deteksi Penyakit Akibat Kerja Dalam Wijaya C, Jakarta : Penerbit Buku EGC. www.banyumaskab.co.id 